\title{
Vision, Worship, and the Transmutation of the Vedas into Sacred Scripture. The Publication of Bhagavān Vedạ̣ in 1970
}

\author{
Borayin Larios | ORCID: 0000-0001-7237-9089 \\ Institut für Südasien-, Tibet- und Buddhismuskunde, Universität Wien, \\ Vienna, Austria \\ borayin.larios@univie.ac.at
}

\begin{abstract}
This article discusses the first Indian compilation of the four Vedic Saṃhitās into a printed book in the year 1971 entitled "Bhagavān Vedah." This endeavor was the life's mission of an udāsinn ascetic called Guru Gañgeśvarānand Mahārāj (1881-1992) who in the year 1968 founded the "Gangeśvar Caturved Sansthān" in Bombay and appointed one of his main disciples, Svāmī Ānand Bhāskarānand, to oversee the publication of the book. His main motivation was to have a physical representation of the Vedas for Hindus to be able to have the darśana (auspicious sight) of the Vedas and worship them in book form. This contribution explores the institutions and individuals involved in the editorial work and its dissemination, and zooms into the processes that allowed for the transition from orality to print culture, and ultimately what it means when the Vedas are materialized into "the book of the Hindus."
\end{abstract}

\section{Keywords}

Vedas - bibliolatry - materiality - modern Hinduism - darśana - holy book

"Hey Amritasya Putra-O sons of the Immortal. Bhagwan Ved has come to give you peace. Bhagwan Ved brings together all Indians and spreads the message of Brotherhood. Gayatri Maata is there in every state of India. This day is indeed very auspicious for India but 
for me it is still more significant because it was my Gurudev's wish that I learn Sanskrit and spread the message of Vedas all around the world. By merely having the Darshan of the book people will feel blessed. The study of Vedas is important not only for Indians but also for all Mankind. This book will now be presented in all temples, universities, libraries and other places of worship." [sic.]

- GURU GANंGEŚVARĀNAND MAHĀRĀJ, during the first installation of the Veda in Mumbai, $1971^{1}$

Arguably, the first Indian compilation of the four Vedic Saṃhitās 2 into a single printed book was accomplished in the year 1971 and was entitled "Bhagavān Vedah" or the "venerable Lord Veda." The aim of this article is threefold: first, to briefly investigate the transmutation of the Vedas from a strictly oral tradition to one in which they become not only a scripture, but the book itself becomes a "sacred object" of worship, an artifact to be worshipped whose mere physical presence conveys blessings and potentially even liberation; second, to trace the sources of this bibliophilic discourse; ${ }^{3}$ and finally, to underscore the integration of this discourse into contemporary forms of guru-centric Hinduism, in which the Vedas have mainly become a token of authority in service of a more

1 Available at: http://gurugangeshwaranandjimaharaj.org/?p=5020, accessed July 10, 2020.

2 The term samhitā commonly refers to the continuous recitation of the initial and main part of each of the four Vedas. The term is often translated as "collection" or "bundle" (of texts). However, in the Vedic context it refers rather to those recited texts whose words are "joined" (samhit $\bar{a})$ without any gaps between them. In contrast, a text containing words that are individually separated is called pada-patha or word-by-word (text). For a discussion of the term saṃhitā in Pāninian terms, see for example Madhav Deshpande, "From Orality to Writing: Transmission and Interpretation of Pāṇini's Așțādhāyi," in Veda-Vedānga and Avesta Between Orality and Writing, eds. Julieta Rotaru and Jan E.M. Houben, The third section-Euroasiatic and Afroasiatic Studies III (Bucharest: Bibliothèque Métropolitaine de Bucarest, 2011), eds. Jan Houben and Julieta Rotaru (Bucharest: Bibliothèque Métropolitaine de Bucarest, 2011). For a description of the canonic formation of the Vedic corpus into four Vedas in the late Vedic period, see Frits Staal, Discovering the Vedas: Origins, Mantras, Rituals, Insights (New Delhi: Penguin, 2008), 69-86.

3 I use the term "discourse" here in the broadly Foucaudian sense, namely, as bodies of knowledge that include both verbal narratives and social practices by which individuals imbue reality with meaning (Michel Foucault, Archaeology of Knowledge, 2nd ed., Routledge Classics (Hoboken: Taylor and Francis, 2013). doi:10.4324/9780203604168). 
universalistic neo-vedantic ${ }^{4}$ discourse as "the book of the Hindus." The article thus explores how the printed production of a body of textual knowledge that until recently had been primarily mediated orally could become commodified into an iconic book, engendering new attitudes and ritual practices focused on it, but also how, specifically in this case, this has contributed to solidifying a discourse of Hinduism as a "religion of the book" that can have political consequences for Hindus around the world.

Although there are a few earlier exceptions, most Vedic texts were written down for the first time during the early second millennium CE. Given the primarily oral nature of these texts, however, it is ironic that even today almost all printed editions of the Vedas "depend on the late manuscripts that are hardly older than 5 oo years, not on the still extant and superior oral tradition." ${ }^{5}$ Orality has largely remained an ideal of the orthodox brähmana $a^{6}$ up to the present day, despite the introduction of writing, print, and mass distribution of texts. ${ }^{7}$ Even if a considerable number of manuscripts and a few printed editions of Vedic texts were indeed produced in the past few centuries, these were neither addressed to a wider public, nor were they meant to circulate freely or prescribed to be read or recited publicly. Therefore, the scale of this process of circulation cannot be compared to conventional publishing. While the enterprise of Guru Gangeśvarānand Mahārāj was unique, it was certainly not the first publication of the Veda. There were indeed a few other printing ventures

4 By using the problematic term neo-vedāntic here, I refer specifically to discourses that were mobilized and emphasized during the late eighteenth and nineteenth centuries to assert a Hinduism that was inclusive, rational and universal. Hindu Reformers proposed such discourses largely as a response to the colonial critique of Hinduism. The most recognized proponents of this new form of Hindu discourse were spiritual intellectuals such as Svāmī Vivekānanda or Sri Aurobindo. For a discussion of the problematic use of the term "Neo-Vedānta," see Andrew J. Nicholson, Unifying Hinduism: Philosophy and Identity in Indian Intellectual History, South Asia across the disciplines (New York: Columbia University Press, 2010), doi:10.7312/nich14986, http://www.jstor.org/stable/10.7312/nich14986 and James Madaio, "Rethinking Neo-Vedānta: Swami Vivekananda and the Selective Historiography of Advaita Vedānta," Religions 8, no. 6 (2017), doi:10.339o/rel8o6o101.

5 Stephanie Jamison and Michael Witzel, "Vedic Hinduism," in The Study of Hinduism, ed. Arvind Sharma, Studies in comparative religion (Columbia, S.C.: University of South Carolina Press, 2003), 69 .

6 I define an "orthodox brāhmana" as someone who strives to embody the ideal qualities and behavior of a brāhmaṇa as presented in authoritative Brahmanic texts such as those codified in the Dharmaśāstra literature, the epics and other literary genres.

7 Borayin Larios, Embodying the Vedas: Traditional Vedic Schools of Contemporary Maharashtra (Warsaw, Berlin: De Gruyter Open, 2017), doi:10.1515/9783110517323; Cezary Galewicz, Kingdoms of Memory, Empires of Ink: The Veda and the Regional Print Cultures of Colonial India (Krakow: Jagiellonian University Press, 2020), 37. 
by Indian publishers from around 1870 to $188 \mathrm{o}$. However, the intended users of these editions of the Veda were not the wider public, but brähmana students and pandits or, even more evident, missionaries and Orientalists. However, none of these early publications attempted to compile all four Vedas into a single volume. ${ }^{8}$

Despite such efforts, until the 1970s the Veda remained an intellectual property held within a very limited number of hands. It was transmitted in two interconnected streams: memory reproduction systems on the one hand, and regional manuscript cultures on the other. In the prevailing orthodox ideology of transmission, it is required that the Veda be sheltered and protected from corruption and improper use by the ignorant. As has been noted by many scholars, for centuries orthodox beliefs zealously guarded the Veda against being written down, and while the Vedic texts were finally indeed committed to writing and became objects in the form of manuscripts (and more recently in the form of printed books), until today the Vedas have remained largely within the domain of mantra and therefore of sound and not of meaning per $s e .{ }^{9}$ Recent scholarship, however, has also demonstrated that manuscripts of the Veda were also used in ways different than one might expect, notably as

8 A notable exception is perhaps the missionary endeavor of Rev. John Stevenson of the Church of Scotland, who in 1883 published an edition and translation of the Veda entitled The Threefold Science in Bombay. This edition, however, excluded the Atharvaveda. See also footnote 10 below. For more on Stevenson's publication, see: Cezary Galewicz, "The Missionaries in the Race for Putting the Veda to Print: Rev. John Stevenson and His 'Threefold Science' of 1833," Cracow Indological Studies 21, no. 1 (2019), doi:10.12797/CIS.21.2019.01.06 and Galewicz, Kingdoms of Memory, Empires of Ink.

9 Many scholars have argued for the centrality of the mantras as sound. Staal's argument based on Kautsa's view of the intrinsic meaninglessness of mantras (Staal, Discovering the Vedas 191-94) has also been at the center of academic debate for a few decades now, perhaps most famously in the volume edited by Harvey P. Alper, ed., Understanding Mantras (Delhi: Motilal Banarsidass, 1991). Staal, paraphrasing Kautsa's position, asserts that for orthodox brāhmanas "[t]here is a tradition for mantras to be learnt by heart, but no corresponding tradition to teach and thereby preserve their meaning" (Staal, Discovering the Vedas, 144). Other scholars such as Robert Yelle disagree with Staal's claim that mantra is not language and thus that a mantra is intrinsically meaningless. Yelle writes "[t]he most appropriate analogy for mantras is neither baby-talk, nor bird songs, nor even music, but poetry. And poetry is no 'pre-linguistic language,' but language par excellence, heightened, augmented, and therefore communicative and effective" (Robert A. Yelle, Explaining Mantras: Ritual, Rhetoric, and the Dream of a Natural Language in Hindu Tantra, Religion in History, Society, and Culture 3 (New York, London: Routledge, 2003), 19). Be that as it may, most scholars and mantra-practitioners, whether Vedic or not, still concede that mantras are primarily about sound/vibration and that this sonic medium is crucial to one's understanding of them. 
ritual objects..$^{10}$ I have argued elsewhere that within the orthodox Vedic tradition, it is still human beings who embody the texts pertaining to the four Vedas and not the other way around. ${ }^{11}$ Printing and publishing of the Veda in early modern India must have been a risky endeavor, not only because the readership of such a publication would be difficult to find, and thus the chances for commercial success very poor, but also because of the expected resistance of those who feared the Vedas could fall into the wrong hands (or ears). ${ }^{12}$ Therefore, while the Vedas have arguably been the cornerstone of Hinduism for many, their accessibility has been largely mediated through brahmanical hierarchies that seek to maintain ritual purity and ultimately control over "sacred knowledge." This accounts for the fact that the earliest printing initiatives known from the Indian subcontinent did not include Vedic texts, but rather publications of the Bible translated into a number of Indian vernaculars, grammars of vernacular languages, and other texts generally meant for mass distribution or missionary work. However, that the Vedas were not edited and published in printed form was not due to a lack of interest on the part of Europeans and missionaries in particular; quite the contrary, for them the Vedas were a mystery to be solved. "The Vedas seem to have haunted the imagination of travelers, traders, conquerors and missionaries from their first encounters with legends and hearsay about the brahmanical books long before any of the Vedic texts were actually seen."13 Despite the limited success of missionaries trying to get their

10 The production, circulation and use of the Veda as a material object becomes a central feature in puranic ritual contexts, notably in the Sivadharma and Viṣnudharma corpora. For more on the cultic aspect of Veda manuscripts, see Florinda de Simini, Of Gods and Books: Ritual and Knowledge Transmission in the Manuscript Cultures of Premodern India, Studies in manuscript cultures Volume 8 (Berlin, Boston: De Gruyter, 2016), doi:10.1515/9783110478815 and Cezary Galewicz, "Let Śiva's Favour Be Alike with Scribes and with Reciters': Motifs for Copying or Not Copying the Veda," in Veda-Vedānga and Avesta Between Orality and Writing, eds. Jan Houben and Julieta Rotaru (Bucharest: Bibliothèque Métropolitaine de Bucarest, 2011). For more on the iconic aspect of books in general, see, for example, James W. Watts, How and Why Books Matter: Essays on the Social Function of Iconic Texts, Comparative Research on Iconic and Performative Texts (Sheffield: Equinox Publishing, 2019).

11 Larios, Embodying the Vedas.

12 There are numerous passages in the epics and later literature that prohibit committing the Veda to writing, but also severe punishments for those who listen to the Vedas or dare to recite Vedic mantras who should not, such as those enumerated by several dharmaśāstric authorities (see for example Hartmut Scharfe, Education in Ancient India, Handbook of oriental studies. Section two, India v. 16 (Leiden, Boston: Brill, 2002), 198-99). For a general overview of the Brahmanical attitude towards guarding the Vedas orally, see Scharfe, Education in Ancient India, 8-37 and Larios, Embodying the Vedas, 19-30.

13 Galewicz, "The Missionaries in the Race for Putting the Veda to Print," 29. 
hands on the Vedas and to publish Vedic texts, as in the example of Stevenson's The Threefold Science, the Vedas were inaccessible for the general public during most of the colonial period and have remained so even until today. ${ }^{14}$ It was due to this restricted access and the living oral transmission of the Vedas that Frits Staal famously wrote: "If there is one thing the Vedas are not, it is books." ${ }^{15}$ In this article, I attempt to show that, contrary to a purist conception of what the Vedas ought to be, they indeed have become books, in any case for many missionaries and Orientalists, but also for a number of Hindus themselves. Neither of these groups are the traditional custodians of the Vedic oral tradition, but at least for a number of Hindus who consider themselves staunch devotees and protectors of "sanatana dharma,"16 the project of printing the Vedas in a single volume was no less of a meritorious act.

This article will not be able to trace all the complexities involved in the transmutation of the Vedas into a material scripture comparable to the Bible or the Qurān, but it is important to note that this process was accelerated by the introduction of the printing press, orientalist imagination, and the Hindu reform movement of the nineteenth century. ${ }^{17}$ The contribution of this article is to present a particular example of an individual who had the four Vedas (or rather a particular selection thereof) ${ }^{18}$ put together into a single book with a distinct intention in mind, namely to compile a single volume that could be worshiped and revered by all Hindus. This endeavor was the life mission of an udāsin ascetic called Guru Gangeśvarānand Mahārāj, who in the last years of his life in the late 196os appointed one of his main disciples (and current head

14 The conception of the three Vedas as the "triad of knowledge" (trayı vidyā) excluding the Atharvaveda was relatively widespread in early India. In certain Brahmanical circles the position of the Atharvaveda as a source of Vedic authority has remained peripheral even until the present day. Note that even for Stevenson, for example, the Veda comprised three and not four types of knowledge. Staal also points out that "[ $t$ ]he 'The Three Vedas' are still the only ones mentioned in Buddhist texts and in the law code of Manu (second century CE). Four Vedas are mentioned in the Mahabharata epic and in later literatures" (Staal, Discovering the Vedas, 135).

15 Staal, Discovering the Vedas, 135 .

16 The term sanātana dharma which translates to "eternal law" or "eternal order" is a Neo-Hindu denomination to refer to Hinduism as a "way of life" in contrast to a manmade religion. For a critical discussion of the term see John Zavos, "Defending Hindu Tradition: Sanatana Dharma as a Symbol of Orthodoxy in Colonial India," Religion 31, no. 2 (2001), doi:10.10o6/reli.2001.0322.

17 Recent work by Galewicz has done great service in providing a detailed account of the Veda's regional print cultures in colonial India (Galewicz, Kingdoms of Memory, Empires of Ink).

18 This selection of Vedic texts will be discussed in more detail below. 
of the udāsin tradition), Svāmī Ānand Bhāskarānand, to oversee the publication of the Vedas into one book.

\section{Guru Gaṅgeśvarānand Mahārāj}

According to hagiographic accounts, Guru Gañgeśvarānand Mahārāj (figure 1) was born in a brāhmaṇa family in Punjab in 1881 as Candeśvara Śarma. When he was very young his mother passed away, and when he was five years old, he became blind as a result of chicken pox. Soon after that his father, Pandit Rāmadatta Śarma, left him under the care of an udāsīn saint named Svāmī Rāmānand. Following his traditional education, his guru gave him the ascetic initiation into the udāsin sect during the Kumbha Melā of 1903 in Haridwar, giving the then 22-year-old the name Gangeśvarānanda. According to one of his hagiographies, after many years under Svāmī Ramānand's tutelage, he succeeded his guru as the seventeenth head of the udāsin sect, which claims that the "lineage [was handed down] from Sant Kumar, son of Lord Brahma, the creator." ${ }^{19}$ Guru Gangeśvarānand Mahārāj thus became the head of the udāsinns of the southern dhüni. According to hagiographic narratives, the southern dhūnī goes back to Balu Hasne, one of the four main disciples of Śrī Cand. Historically, the udāsin ascetic sect is said to have originated from either Guru Śrī Cand or Bābā Gurditta. ${ }^{20}$ The former was the eldest son of Guru Nānak, the founder of the Sikh religion, and the latter was the eldest son of the sixth Sikh guru, Hargobind. The followers of the $u d \bar{a} \sin$ sect are sometimes referred to as nānak-putras, or the "sons of Nānak." According to Oberoi (1994), early Sikh history records ten $u d \bar{a} \sin$ orders, of which some have survived up to the present day. The udāsin traditions were nonetheless excluded from the Sikh community when in the eighteenth and nineteenth centuries, the khālsa order took over the religious power of the previously heterogeneous and nonexclusive Sikh groups. This process took a particularly decisive turn under the Singh Sabhā's project of "purging Sikhism from all its diversity," a project that included expelling ascetic branches such as the $u d \bar{a} \operatorname{sins} .^{21}$

Among udāsinns today, it is more common to find Hindu rather than Sikh religious traits. In fact, references to a Sikh heritage are rarely mentioned openly in

\footnotetext{
19 Arjan Advani, "Swami Gangeshwaranandji Maharaj: A Unique Saint of the Century," http://gurugangeshwaranandjimaharaj.org/?p=4867.

20 Harjot Oberoi, The Construction of Religious Boundaries: Culture, Identity, and Diversity in the Sikh Tradition (Chicago: University of Chicago Press, 1994).

21 Oberoi, The Construction of Religious Boundaries.
} 
udāsin congregations nowadays. Emphasis is clearly put on Hindu scriptures, such as the Bhagavadgitā, the Bhāgavata Purāna or the Rāmāyaṇa, and notably the Vedas, as well as on ritual Hindu practices such as püja. In addition, the majority of udāsins today adhere to the broad notion of sanātana dharma and not to the sikh dharma or gurmat (literally the "teachings of the gurus"). The followers of Guru Ganigeśvarānand Mahārāj are largely caste Hindus, most of them hailing from North India, particularly around the cities of New Delhi and Mumbai and the regions of Amritsar (Punjab) and Vrindavan (Uttar Pradesh). The three main udāsin āśrams are located in Mumbai, Delhi and Vrindavan, respectively. The last is known as Śrauta Muni Nivās and has a large memorial dedicated to Guru Gañgeśvarānand Mahārāj known as Smārak Bhavan. In addition, there is a Sanskrit university called Udāsīna Saṃskṛta Mahāvidyālāya in Varanasi. The university was established in 1930 by Svāmī Kṛṣnānanda Mahārāj and was later put under Ganggeśvarānand's leadership. It is now funded and managed by Ganggeśvarānand's trust.

Guru Gañgeśvarānand Mahārāj allegedly lived for 111 years and passed away in 1992. He was (and still is) perceived by his devotees as "[someone who] dedicated all his life to Bhagavān Ved. The very objective of his life is to propagate Vedic knowledge in the various countries all over the world and make human life meaningful."22 As I have written elsewhere, Guru Gangeśvarānand Mahārāj drew considerable inspiration for his religious discourse from the Hindu reformers of the nineteenth century, in particular from north Indian networks within the reactionary sanātana dharmīs and from Hindu nationalists in the Hindi-belt at large. ${ }^{23}$ Gangeśvarānand also had a modest following in South India, although he is not well known south of Maharashtra. This is also true for

22 Translated from a brochure in Hindi published by Matośrī Rāmpyārībaī Sāraḍā Dharmik Pratișțān, who also built the Veda Mandir in Nashik, Maharashtra (see Larios, Embodying the Vedas, 188-98). The brochure reads in Hindi: ... gurudeva sampūrna jīvana veda bhagavāna ko samarpita hai. unke jīvana kā uddeśya hi vaidika jñāna kā deśa-videśa maim prasāra kara mānava mātra ko sārthaka banānā hai.

23 Gangeśvarānand expounded a rather universalistic tone in his teachings. Nonetheless, he also promoted a very open nationalism, although not necessarily of the Sangh Parivar variant, and expressed his political affiliation more or less openly to his devotees. He was a supporter of Jawaharlal Nehru and of the Indian National Congress party, which remained in power after India's independence for almost sixty years. During the partition and later during the wars with China and Pakistan, Gangeśvarānand gave a number of patriotic speeches. According to hagiographic accounts recorded in the book Yogeśvara Guru Gangeśvara Vol. II (Phojadāra 1979, 31-35), it was thanks to the recitation of secret Rgvedic mantras by expert brāhmanas recommended to the then acting Prime Minister Lal Bahadur Shastri that the war against Pakistan was won in 1965 . 


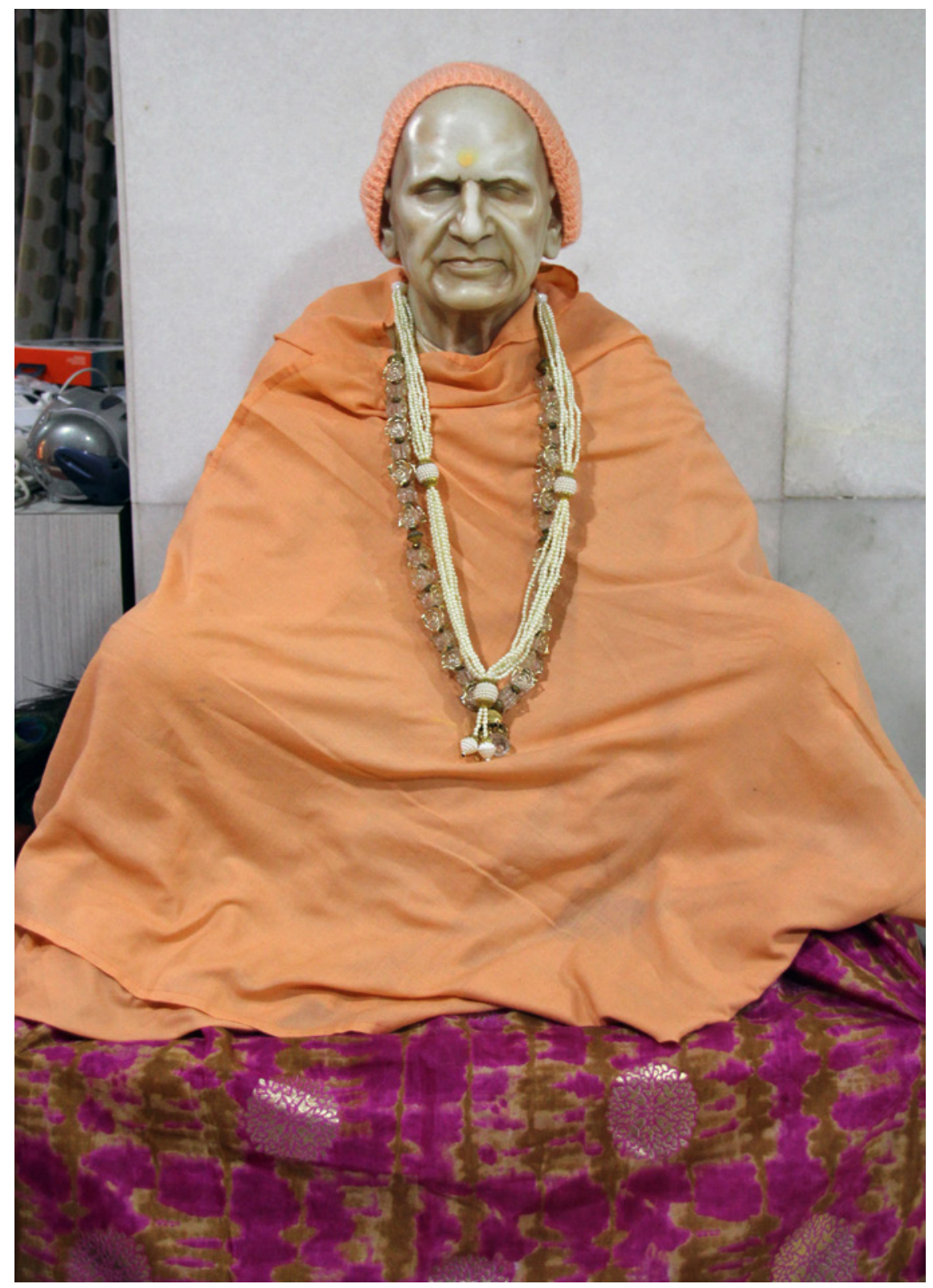

FIgURE 1 Mūrti of Guru Gañgeśvarānand Mahārāj at the Guru Gangeshwar Ved Dham in Mumbai, Maharashtra PHото BY THE AUTHOR 
the udāsin tradition in general, whose footing is mostly in the Hindi-belt and in Punjab.

The discourse that developed out of the Neo-Hindu nationalist movement, which presented a "scientific" and "rational" religion as found in Vedānta, was current in the intellectual milieu in which Gangeśvarānand developed his ideas. By presenting spirituality through a "rational" and "scientific" lens, not only Gañgeśvarānand, but also Rām Mohan Roy, Vivekānanda, Dayānanda Sarasvatī, Aurobindo, as well as many other gurus who followed them, found a friendly echo especially amongst Western-educated Indians. ${ }^{24}$ Many of these nineteenth-century reformers, particularly Dayānanda Sarasvatī and the Ārya-Samājiss as a whole, looked at the Vedas as the main source of inspiration, and attempted to reform Hinduism by cleansing it from impurities such as idol worship and superstition. Their goal was to revive a Vedic golden age based on a way of life "according to the Vedas." 25 As Killingley and other scholars have shown, Dayānanda Sarasvatī owed a great deal to Protestant ideas, especially regarding the centrality of a "holy scripture."26 This process of emulating elements of the colonial powers has been termed "strategic mimetism" by Jaffrelot. ${ }^{27}$ I would argue that strategic mimetism was crucial in shaping a bibliolatry centered on a single "holy book," and yet in the case of Gangeśvarānand the mimetism was not necessarily of Christianity or Islam, but more importantly of Sikh - and by extension the udāsin-attitudes to scripture. The Guru Granth Sähib, in particular, is relevant with regard to the way in which the Vedas are conceived and treated within Gangeśvarānand's tradition. Reverence and worship of "sacred texts" as scriptures (i.e. "sacred objects") are known practices in the Hindu context. This is particularly true in Tantric circles, but

24 Meera Nanda, Prophets Facing Backward: Postmodern Critiques of Science and Hindu Nationalism in India (New Brunswick, [NJ]: Rutgers University Press, 2003).

25 Kenneth W. Jones, Arya Dharm: Hindu Consciousness in 19th-Century Punjab [Wolfgang Laade Music of Man Archive] (Berkeley: University of California Press, 1976).

26 Killingley writes: "While the Bible was not accepted as a unique revelation, the Protestant idea that holy scripture should be read and understood by all, together with the interest shown by European scholars in ancient Sanskrit texts, prompted attempts to make Hinduism what it had hitherto not been, a religion of a book. Dayānanda's was the most thorough-going attempt." Dermot Killingley, "2.05 Dayānanda Sarasvatî:The Light of Truth (India, 1884)," in Religious Dynamics Under the Impact of Imperialism and Colonialism: A Sourcebook, ed. Björn Bentlage et al., Numen Book Series Volume 154 (Leiden, Boston: Brill, 2017), 276.

27 Christophe Jaffrelot, "The Vishva Hindu Parishad: Structures and Strategies," in Religion, Globalization and Political Culture in the Third World, ed. Jeffrey Haynes (Basingstoke: Macmillan, 1999). 
also elsewhere. ${ }^{28}$ Important references are found in medieval Purānas. De Simini notes:

Rituals centered on the worship of scriptures in the form of the veneration of their manuscripts are fairly well attested in the sources belonging to the main Śaiva and Vaiṣnava tantric traditions, ranging from medieval Kashmir to early modern South India. ${ }^{29}$

However, even if some textual passages can be found regarding the worship of "sacred scriptures" in Hinduism, one could argue based on the available evidence that the practice of worshipping a single book or scripture was not something that was particularly widespread, especially for the Veda, which was transmitted largely orally and in specific recensions. Such bibliolatry in the Sikh context, on the other hand, became more prominent with the proclamation of the Sikh Rahit Maryādā by Sikh intellectuals in 1950, which not only outlined the khālsā code of conduct, but also culminated in the definitive enthronement of the Guru Granth Sähib as the sole "living authority" for the Sikhs. The tenth Sikh master, Guru Gobind Singh, had already bestowed the spiritual dimensions of the Guru's authority on the Ädi Granth (now known as the Guru Granth Sāhib) initially housed in the "Golden Temple," or Harimandir, in Amritsar, thus laying the foundation for the personification of the holy book of Sikhism. ${ }^{30}$ In addition to the then newly established orthodox Sikh attitude to their own scriptures (a process that tied in closely with the trends of Hindu reformism and the new formation of religious identities), the $u d \bar{a} \operatorname{sins}$ did not necessarily feel separated from Hinduism at large. ${ }^{31}$

28 For examples in Hinduism, see for instance C. M. Brown, "Purāna as Scripture: From Sound to Image of the Holy Word in the Hindu Tradition," History of Religions 26, no. 1 (1986), doi:10.1086/463061, and De Simini, Of Gods and Books.

29 De Simini, Of Gods and Books.

30 Pashaura Singh, The Guru Granth Sahib: Canon, Meaning, and Authority (New Delhi, New York: Oxford University Press, 2000).

31 In fact, many Sikhs also followed "Hindu" practices and it was difficult to differentiate one religion from the other prior to the numerous Sikh reforms in the eighteenth and nineteenth centuries, as Oberoi has demonstrated. The echoes of social and religious reform were largely the result of the colonial construction of religious boundaries. It is therefore no surprise that Dayānanda Sarasvatī was very popular among Sikh intellectuals when he lived in Lahore in 1877 . Oberoi writes: "[t]he reformatory zeal of the Arya Samaj initially attracted many Sikhs, several of whom became leading members of the Lahore branch." See Oberoi, The Construction of Religious Boundaries, 280. After Dayānanda Sarasvatī left Lahore in 1879, however, most Sikhs who had joined the Ārya Samāj now enlisted in the newly founded Singh Sabhā. 
Therefore, the udāsins were frowned upon by the emerging Sikh orthodoxy for their fluid identity and their association with other Hindu ascetics and practices, specifically the worship of Hindu deities, which ultimately resulted in their being ostracized from the khālsā community. As an example, an udāsinn leader named Keshavanand was heavily criticized by Kartar Singh Lasini from the emerging Akali Dal party for making the following declarations in 1910:

1. All the ten Gurus were the preachers of Sana[n]tan Dharm.

2. Guru Tegh [b]ahadur and four Sahibjadas had sacrificed their lives to save Hindus.

3. Granth Sahib contains many words from [the] Vedas and it is merely a translation of the Vedas.

[...] 10. Even Sikh Gurus supported and paid respect to the Udasi Sadhus but these Khalsas condemned them as they could not understand the Gurus saying $[\mathrm{s}]$ in their right perspective.

Kartar Singh Lasini's response to Keshavanand included the following critique:

[...] 6. Udasi Sadhus pretend to believe and recite the Granth Sahib, but in reality they follow and preach from Upanishad, Panchadasi, Sarag, and Vedant etc. $[$ sic $] .^{32}$

Gangeśvarānand, as the heir of the udāsin tradition, further cemented his allegiance to sanātana dharma by adopting the discourse that saw Hinduism as "a tolerant world religion," while at the same time implicitly distancing himself from khälsā Sikhism. He also preached Hinduism as a form of service to the Indian nation state (deśabhakti) and to humanity at large. For him, the udāsinn tradition was one of the authentic paths to the knowledge and experience of the divine, but his "true innovation" was elevating the Vedas as the quintessential book of his tradition.

\section{Bhagavān Vedah takes the Form of a Book}

Gañgeśvarānand Mahārāj often spoke about the importance of making the contents of the difficult Sanskrit language of the Vedas accessible to everyone in their mother tongue (i.e. Hindi and Panjabi), and to provide devotees with the proper "spiritual" (ädhyātmika) interpretation ${ }^{33}$ of the Vedic mantras. He

32 Brahmanand Udasin 1923, as quoted in Kiranjeet Sandhu, "The Udāsīs in the Colonial Punjab 1849 AD-1947 AD" (PhD Diss., Guru Nanak Dev University, 2011).

33 The translation of the Sanskrit term ādhyātmika as "spiritual" comes from Ganigeśvarānand and his translators. It is worth noting that Gangeśvarānand's interpretations of the Vedic material are always paired with classical Hindu textual sources, such as the Bhagavadgit $\bar{a}$ and the epics, the Bhāgavatapurāna, or other (mostly Vaiṣnava) Sanskrit texts. What 
accomplished this not only by lecturing about the "true meaning" of these texts in his "speeches on the Vedas" (veda-pravācanas), but also by fulfilling his life's mission of having a printed edition of the Vedas which combined all the four Saṃhitās in one volume. His main motivation here was not having a book for the masses to enable them to study the semantic content of the Vedic corpus (vedārtha), but rather to have a physical representation of the four Vedas for Hindus to be able to have the darśana (auspicious sight) of the Vedas and be able to worship them.

In Guru Gangeśvarānand's writings and speeches on the Vedas, one can perceive a very particular interpretation of the Vedic hymns, an interpretation colored with ideas from Reform Hinduism. Noteworthy in this regard is that in his speeches Gangeśvarānand often referred to the wisdom in the Vedas as being "written" as opposed to being spoken or simply contained in an oral corpus. ${ }^{34}$ Whether this was a conscious formulation on his part, or rather an unconscious use of language conventions, it is remarkable that for him and many of his contemporaries, the Vedic corpus is already a written scripture. ${ }^{35}$ For someone visually impaired as he was, it is perhaps even more remarkable to emphasize the sense of vision as a central practice for his devotees, since he had been unable to "read" in the common sense of the word since childhood. One would perhaps expect him to have emphasized the traditional sonic aspect of the Vedas, but instead one can often read about his divine power of

he often does in his exegetic exercise is attempt to demonstrate that "the whole scriptural literature gets its sap and substance from the Vedas." Swami Gangeshwaranand Udaseen, Vedas, a Way of Life: From Yadnya (Sacrifice) To Yoga (Union), with the assistance of Malhara, Sundarlal (translator) (Nasik: Matoshri Rampyaribai Sarda Satkarya Nidhi, 1982), 5. Gangeśvarānand's interpretations very rarely include mention of Sikh material.

In many of his recorded speeches, he uses the Hindi phrase vedom mem likhā hai ... "It is written in the Vedas ..." By contrast, in the English translation of his Vedopadeśacandrikā, titled Vedas, A Way of Life from Yadnya (Sacrifice) To Yoga (Union), one hardly finds the notion of the Vedas in their written form, except, perhaps for the many references to "Indian literature," which includes the Vedas (ibid.).

35 Dayānanda Sarasvatī, while explaining the Vedas as being eternal revelations from a Supreme Lord (whom he calls iśvara or paramätma), sometimes refers to the Vedas as books (pustak or granth), and although he usually uses the form kahātā hai, "it is said," to refer to the contents of the Veda, occasionally he uses the Hindi form likha hai, "it is written," to expound the meaning contained therein. As an example, consider the following phrase in his Satyārtha-prakaśạ where Dayānanda Sarasvatī quotes two Vedic passages from the Yajurveda to make a point about the sun and the earth moving: “... vedom mem likhā hai kī ..." (Svāmī Dayānanda Sarasvatī, Satyārtha-Prakaśặ [The Light of the Truth] (Allahabad: Vedic Yantralay, 1884), 240); in the English translation this reads: “... because it is written in the Veda." Dayananda Sarasvati and Chiranjiva Bharadwaja, Light of truht [i.e. truth]: Or, An English translation of the Satyarth prakash, the well-known work of Swami Dayananda Saraswati, New ed. (New Delhi: Sarvadeshik Arya Pratinidhi Sabha, 1975), 270 (emphasis mine). 
sight (dirya drsții) given to him by God when he lost ordinary eyesight, ${ }^{36}$ and the importance of having the darśana of the Vedas personified.

On 24 September 1968 Gangeśvarānand founded the Ganggeśvar Caturved Sansthān in Bombay and appointed one of his main young disciples and current successor in his lineage, Svāmī Ānand Bhāskarānand (figure 2), to oversee the publication of Bhagavān Vedah.

Ganggeśvarānand's ideas became more concrete during the $24^{\text {th }}$ All India Oriental Conference, held in October 1968 in Varanasi, just one month after the creation of the Gangeśvar Caturved Sansthān. At the conference he met scholars who shared his vision of protecting the Vedas and embarking on the project of printing the four Vedas in one volume. Moreover, he made inquiries about the feasibility of the project, and later had Svāmī Ānand Bhāskarānand pitch it to the Viśveśvarānand Vaidikaśodha Sansthān in his native Hoshiarpur-Punjab, the Svādhya Maṇdal of Paradi in Gujarat, the Nirnay Sagar Press in Mumbai, and even the famous Geeta Press in Gorakhpur. All declined to take on the project at the time. At the conference he also met again the local pandits Narhari Vaijapurkar, Maheshdutt Shukla and Satyaswarup Shastri, all of them eminent scholars in Hindi and Sanskrit literature. According to reports published in Yogeśvara Guru Gañgeśvara ${ }^{37}$ Bhāskarānand had been encouraged by his guru to attend the conference specifically to find experts on the four Vedas to help him to carry out the printing and publication of Bhagavān Vedah.

Narhari Vaijapurkar and Maheshdutt Shukla proposed that the work be carried out in Varanasi, since, according to them, that was the only place where not

36 One of the epithets used by his disciples is Veda-Darśanācarya, which can be translated as "master of Veda-insight/vision," which hints at the visual aspect of his teaching style. According to hagiographic accounts, he lost his eyesight when he was a young boy after having a vision of Lord Kṛșna. In a passage of his unpublished English hagiography, one can read that a saint named Phalāhārī Bābā consoled Ganggeśvarānand's father when his son lost his eyesight as follows: "Panditji calm down. If this has happened in spite of all our efforts to cure Him we must then consider this as the divine will. Please calm down, I am sure something good will come out of this. Do not think that this is the anger of the Gods! On the other hand, think that this [is] a special boon! Your son has had the darshan of the Lord with these eyes so now He does not need the mortal vision. He has been granted a divine insight (Prajna Chakshu) [ sic]...." (unpublished English translation by Geeta Nichlani of Yogeśvara Guru Gangeśvara, vol. 1). The last section of the relevant passage reads in the Hindi original: ve dayāghana kabhī kisikā ahita nahīm karte. unhomne laukika cakșuom ke badale ise divya cakșu pradāna kar diye haiṃ. ise prabhu kā prakopa na samajhakar varadān hi māniye ... uske laukika cakșuom kā sthāna prajñāmaya cakșuom ne le liyā. jo ke draștarya acakșu, aprāṇa, amanā ko dekha cuke, ab un cakșuom ke rahane kā koī artha ne thā. käraṇa usse baḍhkar viśva meṃ koì darśanìya hi nahìm hai. yahī sab soca prakrti ne unhem vāpas le liyā ho. Ratana Phojadāra, Yogeśvara Guru Gañgeśvara Vol. I (Ahmedabad: Pārizād Prințerī, 1965), 52.

Ratana Phojadāra, Yogeśvara Guru Gañgeśvara Vol. II (Ahmedabad: Pārizād Prințerī, 1979). 


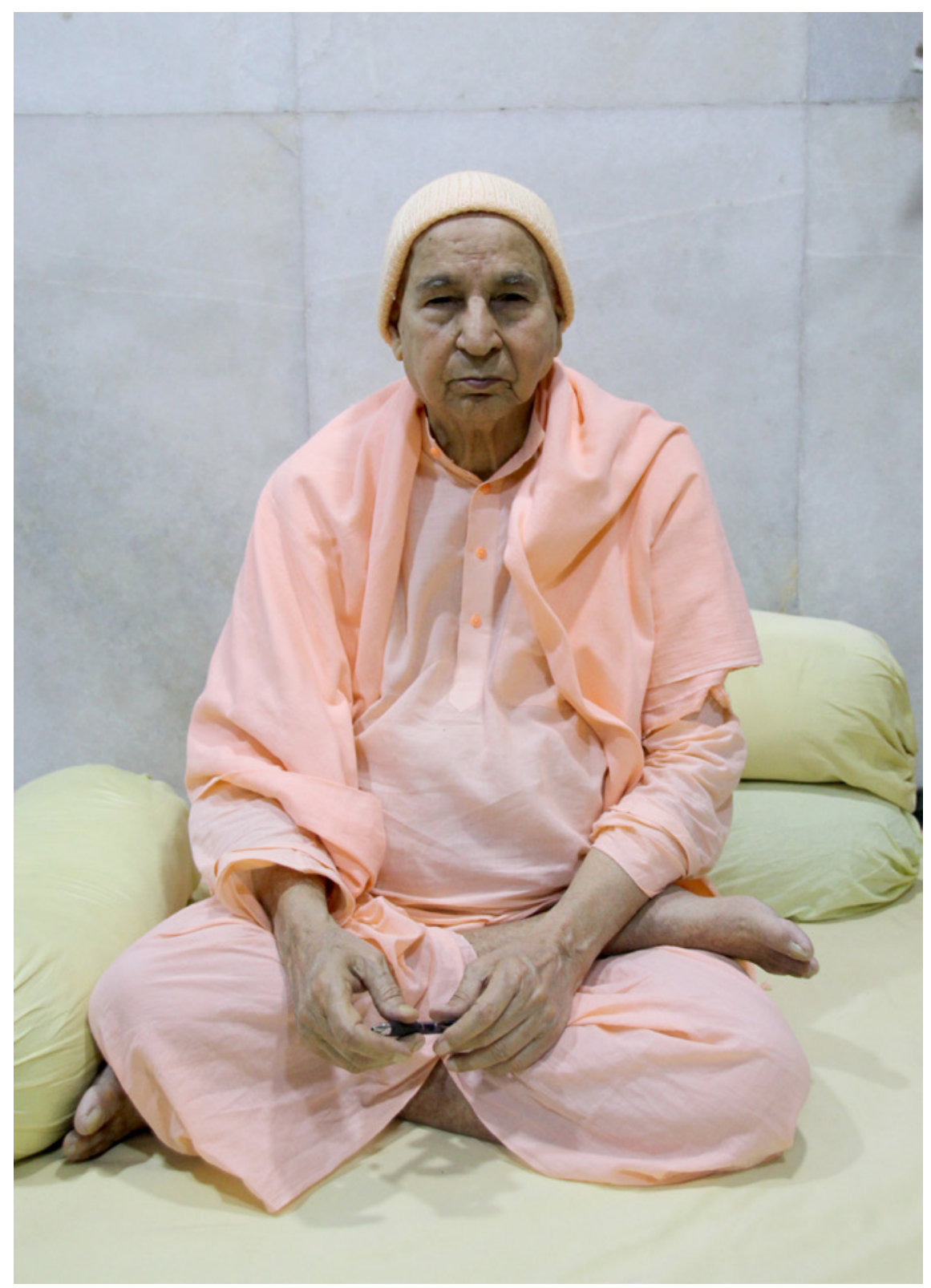

FIGURE 2 Svāmī Ānand Bhāskarānand at the Guru Gangeshwar Ved Dham in Mumbai, Maharashtra. February 2020

PHOTO BY THE AUTHOR 
only Veda reciters (vedapāthīs) of all four Vedas could be found, but also pandits capable of explaining the meaning of the mantras. ${ }^{38}$ As per Gangeśvarānand's wish, the volume would contain the four Vedic Samphitās, but not any other Vedic texts. ${ }^{39}$ While Bhāskarānand was the main editor and manager of the project, the responsibility of editing and organizing the expert committee was given to pandit Narhari Vaijapurkar, who was also to oversee the editing and sourcing of the manuscripts. For reasons of availability and regional (i.e. north Indian) popularity, Bhagavān Vedah contains the four Vedas in the form of specific recensions (śa $k h \bar{a} s$ ) of the Samphitās, which resulted in the following selection: Śākala-śākhā for the Rggveda, Vājasanejimādhyandina-šākhā for the Yajurveda, the Kauthuma-saakkhā of the Sāmaveda, and finally the Śaunaka-śākhā of the Atharvaveda. Narhari Vaijapurkar was a well-known scholar in Varanasi; he was therefore able to mobilize his network to get the necessary support. An expert committee was formed, whereby at least two traditional pandits for each of the four Vedas were appointed. According to the reports, these pandits knew Vedic mantras by heart and were also exegetes of the Vedas. Kashinath Shastri Telang, professor at Benares Hindu University, was also invited to help resolve the various problematic issues that came up. Apparently, while collecting the text material there was a considerable amount of doubt and dispute among the pandits, and sometimes the work was stalled for even several months at a time..$^{40}$ In addition to recruiting suitable scholars for each of the above-mentioned śâkhās, the team also needed a publishing house that would be capable and worthy of printing such a book. After a brief consideration of his options, Bhāskarānand suggested that instead a new publishing house be set up just for the purpose. ${ }^{41}$

In just three years Bhāskarānand managed to bring out the edition of the colossal book: it measures $38 \times 51 \mathrm{~cm}$, has a total of a thousand pages, and weighs $22 \mathrm{~kg}$. According to Ishwar Thadhani, a long-time devotee from Mumbai and currently a trustee of the Khar ashram in Mumbai, "a special paper was sourced from J. K. Mills so that the pages would last for at least a hundred years and there was no use of animal fat." ${ }^{42}$ Another interesting fact is that the book, although it uses a landscape format layout, is bound on the left with cloth in

38 Phojadāra, Yogeśvara Guru Gañgeśvara, 109-11.

39 Other Vedic texts one might imagine being part of such a collection could be, for example, the Brāhmanas, Āranyakas or the Upanișads.

40 Phojadāra, Yogeśvara Guru Gangeśvara Vol. II.

41 Ibid.

42 Private interview with Ishwar Tadhani and Svāmī Ānand Bhāskarānand conducted by the author on January 25, 2020. See also Phojadāra, Yogeśvara Guru Gañgeśvara Vol. II, 108. 
the Western style, not in the Indian pothi style (which opens vertically). ${ }^{43}$ The cover simply reads in golden Devanagari letters: Bhagavān Vedah (figure 3). The book was printed in two colors: saffron and black. The Devanagari text, in a relatively large font-point, is framed by an artistic border depicting some of the utensils used during the śrauta ritual (figure 4). This is not a portable book in any sense of the word, and despite its clear font, its format cannot be considered "reader-friendly" because turning the pages or moving the book from one place to another is not easy due to its size and weight. It is also obvious that the publication of the book was not a commercial venture; indeed, it was not possible to simply buy the book from a bookstore, or even from the publishing house itself. Today it is practically impossible to find any of the thousand copies of the book that were initially produced. Guru Gangeśvarānand said during the first installation of the book in Mumbai: "Bhagwan Ved is invaluable and so we cannot add any value in terms of money, so wherever we present this book we shall not take even one rupee. This will be a present from us." ${ }^{\text {44 }}$

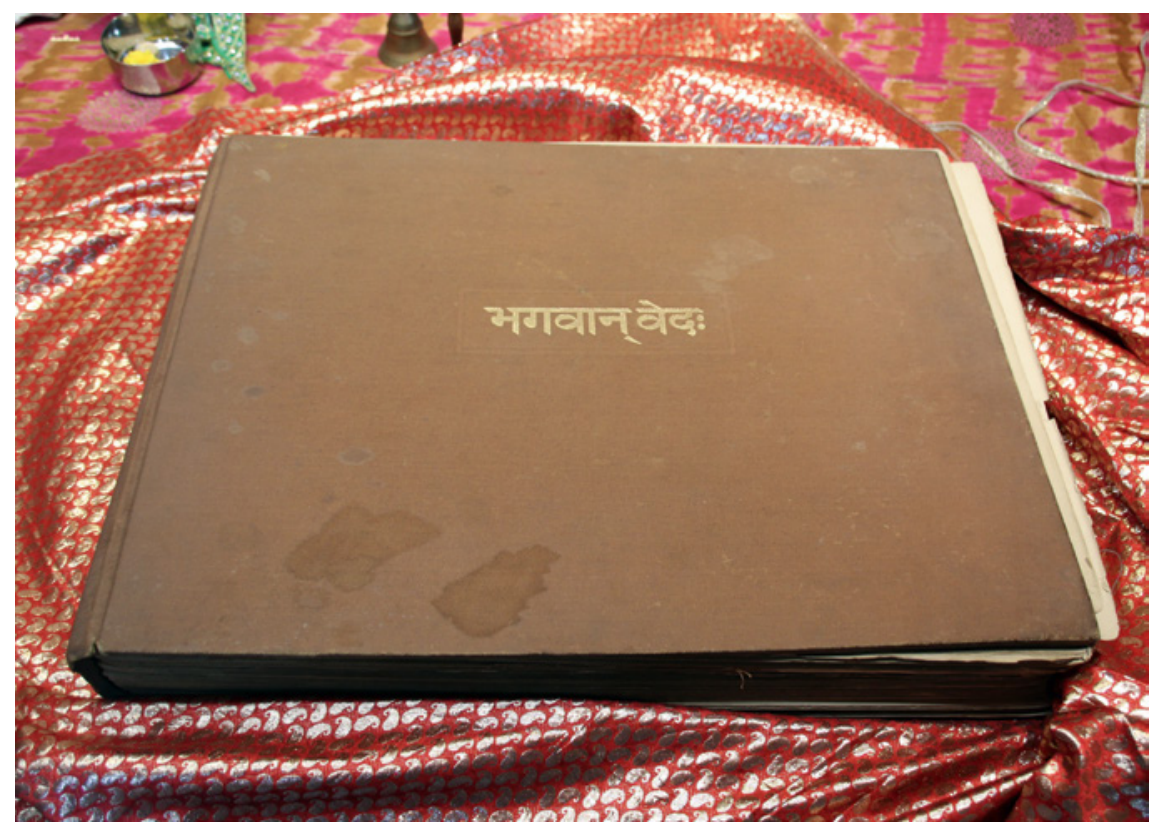

FIGURE 3 Copy of Bhagavān Vedah at the Guru Gangeshwar Ved Dham in Mumbai, Maharashtra

PHOTO BY THE AUTHOR

43 It is interesting to note that also the Guru Granth Sähib is produced using this Western style binding format, not a format imitating typical Indic manuscripts (such as the pothi style).

44 Available at: http://gurugangeshwaranandjimaharaj.org/?p=5020, accessed July 9. 2020. 


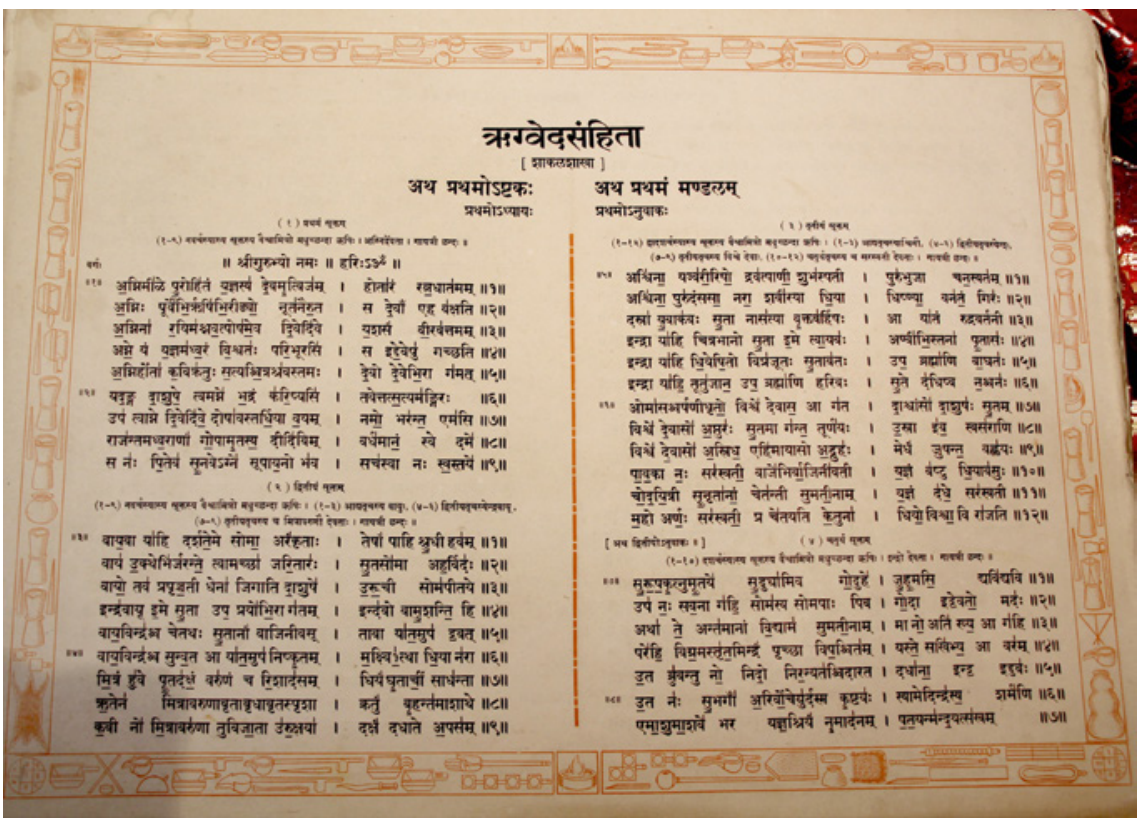

FIGURE 4 First page of the Ṛgedasaṃhitā of Bhagavān Vedah at the Guru Gangeshwar Ved Dham in Mumbai, Maharashtra РНОTO BY THE AUTHOR

\section{Vision, Worship and the Blessings of "Sacred Scripture"}

Om jaya prabhu veda hare svāmījaya prabhu veda hare

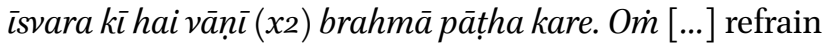

Om victory to the Lord Veda, Hari, the Master! Victory to the Lord of the Vedas!

You are the voice of God, recited by Brahmā

Om $[\ldots]$ refrain

Darśana se bhaya nāśe āgaṇita vighna hare $\left(x_{2}\right)$

Duḥkha jāve sukha āve jo kṑved paḍe. Om [...]

By having your vision one's countless fears and problems are destroyed, o Hari.

Suffering goes and bliss comes for those who recite the Vedas.

- Bhagavān Ved kī Āratī, Verse $1^{45}$

45 The Bhagavān Ved kī Âratī is a devotional song that accompanies the ritual waving of lamps known as āratī, a popular Hindu ritual practice. This song is based on the famous ăratī song Om Jaya Jagdiśa Hare, which was interpreted by Mahendra Kapoor in the 1970 
While the selection of the four Samphitās forming the Vedas for the publication of Bhagavān Vedah is understandable, and to a certain extent to be expected given their widespread symbolic elevation into a fourfold canon over many centuries, ${ }^{46}$ at the same time, materializing them into a single book also re-canonizes these four texts into the only "authentic" or "authoritative" Vedic texts (at least for those less familiar with the richness of the Vedic tradition). One could argue that such a project of scripturalization also removes the Vedas from the oral context in which they abide in the throats of their custodians (kanthastha), and transmutes them into an object with a completely new materiality. As mentioned above, the act of producing such a book was an inventive way of embodying the Veda in a new medium, a way of creating a "mūrti"47 rather than a book for reading in the conventional sense of the word. ${ }^{48}$

The volume of Bhagavān Vedah was ritually installed and treated like a $m \bar{r} r t i$. Guru Gangeśvarānand traveled widely in the last part of his life in order to make people aware of the treasure of Indian civilization contained in the book. His main intention, however, was to ritually install or enthrone the book, just as one would a holy image being consecrated for worship. The term used in the tradition for the handing over of the holy book is called veda-sthāpana, or "the installation of the Veda." The Sanskrit term sthäpana has the

Bollywood film Purab aur Paschim and is now sung all over India. The album containing the Bhagavān Ved kī Âratī, called "The Greatness of the Veda" (Veda Mahimā), appeared in 1992.

46 For more on the question of canon formation and how the Vedic tradition has historically reflected on its own textual boundaries, see the contributions of Carpenter, Smith, and Holdrege, as well as Patton's introduction in Laurie L. Patton, ed., Authority, Anxiety, and Canon: Essays in Vedic Interpretation, suny series in Hindu studies (Albany: State University of New York Press, 1994).

47 Srinivasan explains this as follows: "[i]n the püjā ceremonies performed by a bhakta, the objectified divine is not only a tool to harness the mind in concentration. It is a form that is cherished since it permits the devotee to develop a close, loving relationship with his chosen deity. In both praxes, worship proceeds on the assumption that the object contains the presence of god. The consecrated image, containing the presence of god, represents the last stage in the unfolding process of the deity. The process is a progression beginning from the Transcendental which is formless. A series of progressions terminate with the visible manifestation of god on earth. A particular image, or mürti, represents god's visible manifestation. Into a mūrtī, god's presence is called." Doris Meth Srinivasan, Many Heads, Arms and Eyes: Origin, Meaning and Form of Multiplicity in Indian Art, Studies in Asian art and archaeology 20 (Leiden: Brill, 1997), 14.

48 For other ways of reading, specifically in the religious context, see Paul J. Griffiths, Religious Reading: The Place of Reading in the Practice of Religion (New York: Oxford University Press, 1999). For more on the iconic function of books in different religious contexts, see Watts, How and Why Books Matter. 
connotation of "fastening, fixing, rendering immovable and also placing of" 49 and is a commonly used when referring to the ritual establishment of temples or the installation of deities.

Another claim often made among Guru Gangeśvarānand's followers is that "... no authentic version of all four Vedas was available in one book form" 50 and that the previously available versions were not only full of mistakes, they also contained misunderstandings and corrupt translations by Western scholars that had crept in. ${ }^{51}$ There is thus the notion among his followers that this edition is the only authentic and pure version of the Vedas that has ever been available. This is because the contents are believed to have been verified and corrected by the most learned brähmanas available in Benares (the ancient holy city of brahmanical knowledge), and it was the brähmanas who had faithfully transmitted the tradition orally through millennia. Moreover, the production of this book as a material object was unique: the special paper, special ink and the printing machines were ritually pure (i.e., did not contain any animal products), and were conceived for this project alone. In other words, the publishing house would not print anything else and thus would not be contaminated by any other literature inferior to the Vedas. ${ }^{52}$

With his missionary zeal and the help of individuals and other Hindu organizations, notably the Viśva Hindū Parișad (VHP), Guru Gangeśvarānand founded over five hundred temples in India and abroad. In each temple, he installed Bhagavān Vedah as the main idol. Bhagavān Vedaḥ was not only present as the actual printed book, but also came to be represented in sculpture, as is the case with the "Ved Mandir" located in Nashik, ${ }^{53}$ and even as an anthropomorphic divinity standing on a blooming lotus flower and holding four manuscripts of the Vedas, one on each arm (figure 5), a figure sometimes

49 Monier Monier-Williams, A Sanskrit-English Dictionary: Etymologically and Philologically Arranged with Special Reference to Cognate Indo-European Languages, Repr. from the sheets of the first ed. 1899 (Oxford: Oxford University Press, 2002), 1263.

50 Advani, "Swami Gangeshwaranandji Maharaj".

51 Private interview with Ishwar Tadhani and Svāmī Ānand Bhāskarānand conducted by the author on January 25, 2020 .

$5^{2}$ A curious anecdote pointing to this ritual purity happened when I went to meet Svāmī Ānand Bhāskarānand in Mumbai in February 2020. Mr. Ishwar Thadhani and other people at the Guru Gangeshwar Ved Dham in Mumbai were very helpful in providing me with information and material regarding their tradition. I had brought with me a new USB-stick in case they would have digital material for me. They did kindly offer a number of digital resources, but when I offered my usB-stick, they said that they would prefer to present me a new one. When I told them that there was no need, since I had my own pendrive with me, they insisted on giving me a virgin memory stick and told me that in that way "only material regarding the Vedas would be in the USв."

Larios, Embodying the Vedas, 188-98. 
referred to as veda-narāyaṇa, ${ }^{54}$ or less frequently, veda-purușa ("theVeda-man"). The iconography reminds us of the Rajasthani-style marble idols of Purānic gods found across India and in many Hindu temples around the globe. Guru Gangeśvarānand installed a number of such idols in temples across India and in the diaspora. It is important to note, however, that the personification of the Vedas is not Gangeśvarānand's unique innovation. One can find descriptions of each of the four Vedas anthropomorphized in several Purānas and in some Śrīvidyā texts, something particularly widespread in South India. ${ }^{55}$

Guru Gangeśvarānand also travelled a good part of his later days presenting copies to various select universities, libraries, and educational institutions around the world. By doing so, Guru Gangeśvarānand not only brought India's Vedic scriptural heritage to the limelight of his followers, but also in his tireless missionary zeal helped to cement the idea that the Vedas should indeed be considered the bedrock of Hinduism and the real source of all knowledge. This discourse had already been in circulation in earlier centuries but became particularly important for many of the Hindu reformers of the nineteenth century. However, his innovation was not simply that he solidified the Vedas from an oral corpus of knowledge that had been primarily in the hands of jealous brähmanas, or attempted to elevate the Vedas to being the spiritual and intellectual capital of the Hindus, but rather that he explicitly gave the Vedas a new materiality which, for him and his followers, was to serve as the sine qua non of Hinduism in its totality.

Guru Gangeśvarānand often said in his speeches that "the Veda is indeed the Guru." I argue that this statement is a very Sikh way of treating holy scripture. However, it is interesting that Gangeśvarānand's Hindu disciples continue to acknowledge and revere the authority of the Vedas without necessarily having

54 One of the translations given by Monier-Williams for the term narāyana is "the son of the original Man" (Monier-Williams, A Sanskrit-English Dictionary, 536); it is often used as an epithet for the god Viṣnu.

55 For a detailed account of these mürtis, see Stefano Piano, "A Proposito Delle Murti Dei Veda," in Bandhu: Scritti in Onore Di Carlo Della Casa; in Occasione Del Suo $70^{\circ}$ Compleanno, eds. Renato Arena et al. (Alessandria: Ed. dell'Orso, 1997) and David D. Shulman, "The Enemy Within: Idealism and Dissent in South Indian Hinduism," in Orthodoxy, Heterodoxy, and Dissent in India, eds. David D. Shulman, Reuven Kahane and Shmuel N. Eisenstadt, Religion and Society 23 (Berlin, New York: Mouton, 1984). The particular form of a single god with four arms holding a manuscript of the Veda in each, this sharing Vaișnava iconographic traits of a standing Viṣnunarāyana, is indeed unique. It is not uncommon to find representations of the god Brahmā or other gods such as Matsya and Hayagrīva holding one or more manuscripts representing the Vedas in their hands; however, the iconography of none of these representations is similar to Gangeśvarānand's interpretation of Bhagavān Veda. For a discussion of Hayagrīva's iconography, see Elisa Freschi, “Ven̉kațanātha's Impact on Śrīvaișṇavism," Cracow Indological Studies 21, no. 1 (2019), doi:10.12797/CIS.21.2019.01.05. 


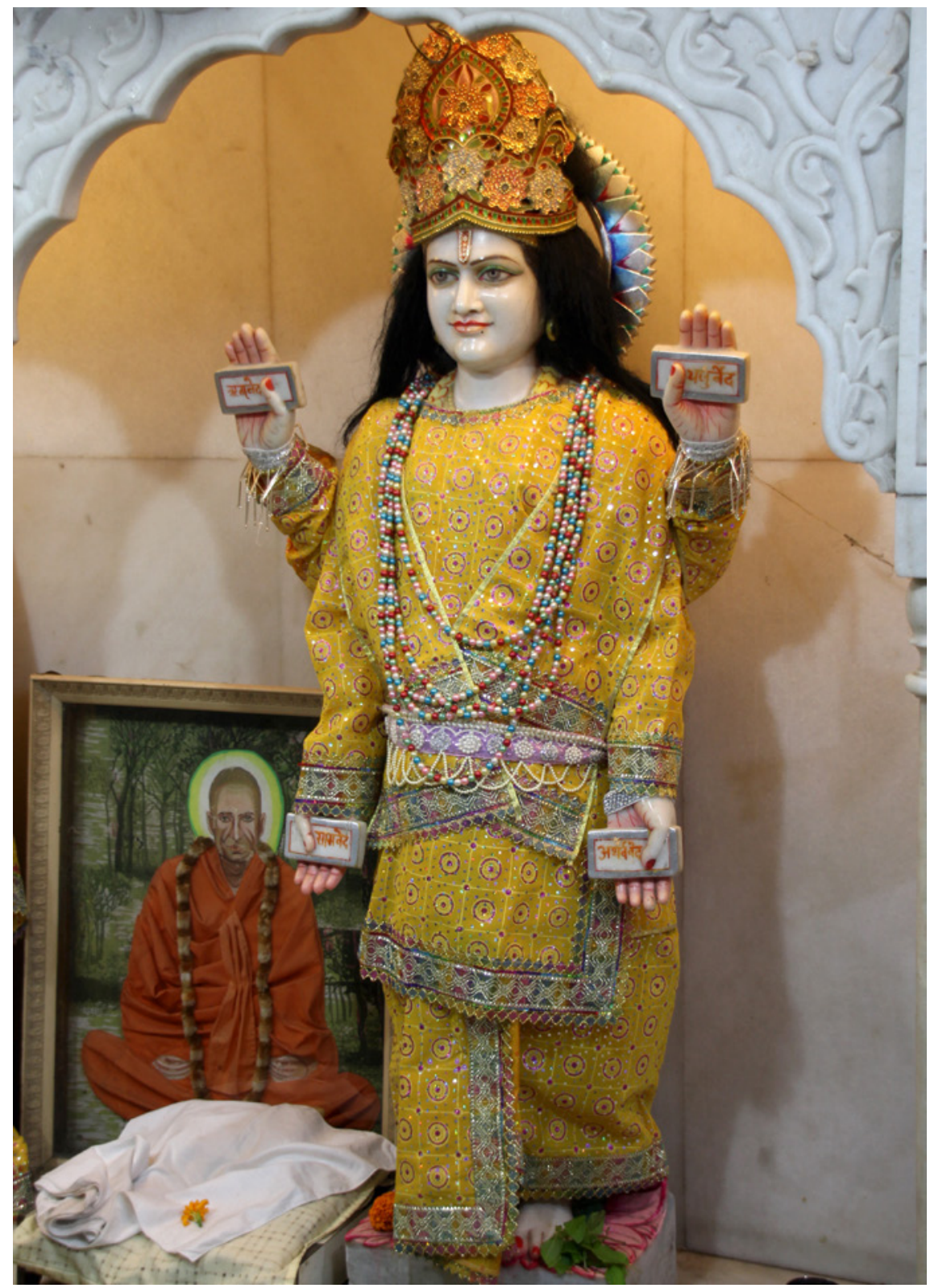

FIGURE 5 Mūrti of Bhagavān Vedanarāyana at the Guru Gangeshwar Ved Dham in Mumbai, Maharashtra

PHOTO BY THE AUTHOR 
read them. Paradoxically, even as the book was presented to prestigious universities and libraries around the globe, its publication and circulation was not necessarily in order that it be "read" (in our common sense of the word), but rather for this new material embodiment to serve an iconic role in the central practice of darśana ${ }^{56}$ It seems that while Gangeśvarānand desired that every Hindu had studied at least a portion of the Vedas, he was probably also aware of the fact that very few had access to a source for their study. The average Hindu does not have knowledge of Sanskrit, and even those who do are not necessarily able to understand the ancient Vedic texts. ${ }^{57}$ He saw the need to study the Vedas was greater for people like him, people who not only had a privileged access to the content of the texts through knowledge of the language, but who had an authentic and deeper knowledge of what is encoded in the Vedas. The solution for him was to transform the Vedas into a "holy book" to be worshipped or, at the very least, regarded as the ultimate and authentic scripture of the Hindus, a book the mere sight of which brings merit and destroys one's sins:

The Vedas are as delightful and elevated as the Himalayas for Indian culture. By one's mere sight of them, all sins can be destroyed. What can one even say if one studies them? The place of origin from which the three holy rivers (triven $\bar{\imath})$ flow is the Himalayas. Likewise, the origin of the three paths of knowledge, devotion, and action is the venerable Lord in the form of the Veda. In the same way that by bathing in the Gangā, Yamunā, and Sarasvatī rivers one is liberated, one too by immersing oneself in the Veda attains freedom. ${ }^{58}$

$5^{6}$ For more about the centrality of this practice in Hinduism, see Lawrence A. Babb, "Glancing: Visual Interaction in Hinduism," Journal of Anthropological Research 37, no. 4 (1981), https://www.jstor.org/stable/3629835; and Diana L. Eck, Darśan: Seeing the Divine Image in India, 3. ed., Translations from the Asian classics (New York, NY: Columbia University Press, 1998).

57 McCartney writes that "[ $t$ ]he recent Indian census estimates that about 15,00o people use Sanskrit on a regular basis, or claim it as their first language. That amounts to 0.00125 percent of India's total population." Patrick McCartney, "The Sanitising Power of Spoken Sanskrit," Himāl-South Asian, 2014, https://www.himalmag.com/sanitising-power-spoken -sanskrit/, accessed April 18, 2021. The percentage of people who can read and understand Sanskrit is probably higher than the number cited here from the census of 2001, but it still amounts to a tiny percentage of all Hindus.

$5^{8}$ Gangeśvarānand, quoted in Phojadāra 1979, 108. Translation by the author. The original Hindi reads: veda to bhāratīya saṃskṛti aur jñāna ke himālaya kī bhāmiti unnata aur ramaṇīya haiṃ. isake darśanamātra se bhūtamātra ke pāpoṃ kā vināsa ho jātā hai. usake adhyayana kā to kahanā hī kyā? jñāna, bhaktiaur karmamārga kī triveñi kā udgama sthāna bhagavān vedarūpī himālaya hì hai. yahì patitapāvanī gaṃgā, yamunā aur sarasvatī kì tarah majjana mātra se muktipradāyī banatī hai. 
The most orthodox brähmanas — or orthoprax, as Staal ${ }^{59}$ would call themwould most likely not adhere to this universalistic and open religiosity, because it threatens to dilute their own identity as the custodians of the Vedas. However, the role of traditional pandits in the editorial process of this particular case, not only not opposing the publication of the Vedas but actively supporting it, shows that at least some traditional pandits did not have a problem with the transmutation of the Vedas into a material book. It was perhaps precisely because they also felt that their tradition was "under attack" by non-Hindus that the discourse seemed attractive of unifying Hinduism against these forces by consolidating the authority of the Vedas. This, while at the same time leaving the Vedas under the domain of the brahmanical male, was perhaps the reason why some pandits agreed to its publication and ultimately to its deification as an anthropomorphic god. This transmutation ultimately did not threaten the oral and ritual command over the Vedas by the brāhmana, but simply expanded their authority symbolically to a broader base. The attitudes and ritual practices that emerged within Gangeśvarānand's tradition reflect his intention to transmute the amorphous form of the Veda into a delightful saguna form. It is an attitude that reflects a common trope in certain bhakti strands of practice, in which the devotee attaches his mind to the qualities (guna) of his deity of choice.

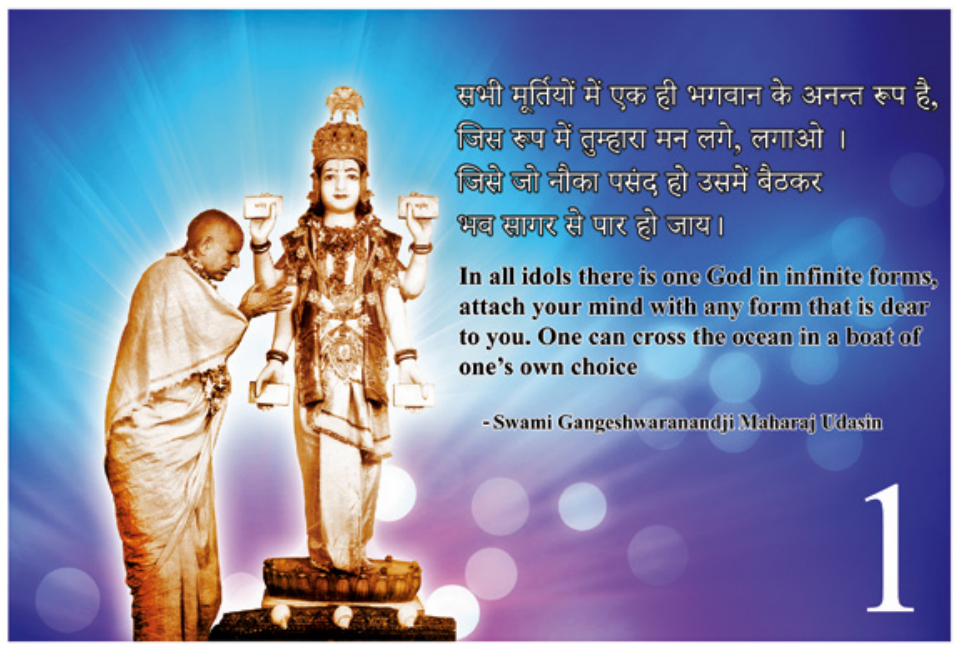

FIGURE 6 Meme created by an anonymous devotee from Dubai and distributed to a network of Gangeśvarānand's devotees via WhatsApp. The image shows Gangeśvarānand worshipping Bhagavān Vedanarāyaṇa and a quote in the original Hindi with an English translation. 
I will conclude with the above meme (figure 6), forwarded to me via WhatsApp by one of Gangeśvarānand's lifelong devotees. ${ }^{60}$ It illustrates how the chosen form of God (ișta-devatā) worshipped by Gangeśvarānand was the oral texts he had turned into the central Hindu scripture for his followers, and ultimately into an iconic god worthy of worship.

\section{Acknowledgments}

Parts of this article elaborate on topics also discussed in Larios 2011 and Larios 2017. I would like to thank the editors of this issue, Cristina Pecchia, Johanna Buß and Alaka Chudal, for their valuable comments on an earlier version. I also extend my gratitude to the two anonymous reviewers who offered suggestions on how to improve this article. A special thank you to Smriti Wadhwa and Ishwar Thadhani for all their help during my fieldwork in 2020, and for introducing me to Svāmī Ānand Bhāskarānand.

\section{Bibliography}

Advani, Arjan. "Swami Gangeshwaranandji Maharaj: A Unique Saint of the Century." http://gurugangeshwaranandjimaharaj.org/?p=4867.

Alper, Harvey P., ed. Understanding Mantras. Delhi: Motilal Banarsidass, 1991.

Babb, Lawrence A. "Glancing:Visual Interaction in Hinduism."Journalof Anthropological Research 37, no. 4 (1981): 387-401. https://www.jstor.org/stable/3629835.

Brown, C. M. "Purāna as Scripture: From Sound to Image of the Holy Word in the Hindu Tradition." History of Religions 26, no. 1 (1986): 68-86. doi:10.1086/463061.

Dayānanda Sarasvatī, Svāmī. Satyārtha-Prakaśah [The Light of the Truth]. Allahabad: Vedic Yantralay, 1884.

Deshpande, Madhav. "From Orality to Writing: Transmission and Interpretation of Pāṇini's Aștāāhāyi." In Veda-Vedānga and Avesta Between Orality and Writing. Edited by Julieta Rotaru and Jan E.M. Houben, 57-100. The third section-Euroasiatic and Afroasiatic Studies III. Bucharest: Bibliothèque Métropolitaine de Bucarest, 2011. Eck, Diana L. Darśan: Seeing the Divine Image in India. 3. ed. Translations from the Asian classics. New York, NY: Columbia University Press, 1998.

6o Similar images are circulated among devotees in India on a regular basis. This particular devotee has created an image to be shared for each day of the month. That is why the image also has a large numeral one in the bottom-right corner. This image is shared with permission of the author who wishes to remain anonymous. 
Foucault, Michel. Archaeology of Knowledge. 2nd ed. Routledge Classics. Hoboken: Taylor and Francis, 2013. doi:10.4324/9780203604168.

Freschi, Elisa. "Ven̉kațanātha's Impact on Śrīvaiṣnavism." Cracow Indological Studies 21, no. 1 (2019): 107-36. doi:10.12797/CIS.21.2019.01.05.

Galewicz, Cezary. "The Missionaries in the Race for Putting the Veda to Print: Rev. John Stevenson and His Threefold Science of 1833." Cracow Indological Studies 21, no. 1 (2019): 137-64. doi:10.12797/CIS.21.2019.01.06.

Galewicz, Cezary. Kingdoms of Memory, Empires of Ink: The Veda and the Regional Print Cultures of Colonial India. Krakow: Jagiellonian University Press, $202 \mathrm{O}$.

Gangeshwaranand Udaseen, Swami. Vedas, a Way of Life: From Yadnya (Sacrifice) To Yoga (Union). With the assistance of Malhara, Sundarlal (translator). Nasik: Matoshri Rampyaribai Sarda Satkarya Nidhi, 1982.

Griffiths, Paul J. Religious Reading: The Place of Reading in the Practice of Religion. New York: Oxford University Press, 1999.

Jaffrelot, Christophe. "The Vishva Hindu Parishad: Structures and Strategies." In Religion, Globalization and Political Culture in the Third World. Edited by Jeffrey Haynes, 191-212. Basingstoke: Macmillan, 1999.

Jamison, Stephanie, and Michael Witzel. "Vedic Hinduism." In The Study of Hinduism. Edited by Arvind Sharma, 65-113. Studies in comparative religion. Columbia, S.C.: University of South Carolina Press, 2003.

Jones, Kenneth W. Arya Dharm: Hindu Consciousness in 19th-Century Punjab. [Wolfgang Laade Music of Man Archive]. Berkeley: University of California Press, 1976.

Killingley, Dermot. "2.05 Dayānanda Sarasvatī: The Light of Truth (India, 1884)." In Religious Dynamics Under the Impact of Imperialism and Colonialism: A Sourcebook. Edited by Björn Bentlage et al., 273-92. Numen Book Series Volume 154. Leiden, Boston: Brill, 2017.

Larios, Borayin. Embodying the Vedas: Traditional Vedic Schools of Contemporary Maharashtra. Warsaw, Berlin: De Gruyter Open, 2017. doi:10.1515/9783110517323.

Madaio, James. "Rethinking Neo-Vedānta: Swami Vivekananda and the Selective Historiography of Advaita Vedānta." Religions 8, no. 6 (2017): 101. doi:10.339o/ rel8o6o101.

McCartney, Patrick. "The Sanitising Power of Spoken Sanskrit." Himāl—South Asian, 2014. https://www.himalmag.com/sanitising-power-spoken-sanskrit/.

Monier-Williams, Monier. A Sanskrit-English Dictionary: Etymologically and Philologically Arranged with Special Reference to Cognate Indo-European Languages. Repr. from the sheets of the first ed. 1899. Oxford: Oxford University Press, 2002.

Nanda, Meera. Prophets Facing Backward: Postmodern Critiques of Science and Hindu Nationalism in India. New Brunswick [NJ]: Rutgers University Press, 2003. 
Nicholson, Andrew J. Unifying Hinduism: Philosophy and Identity in Indian Intellectual History. South Asia across the disciplines. New York: Columbia University Press, 2010. doi:10.7312/nich14986. http://www.jstor.org/stable/10.7312/nich14986.

Oberoi, Harjot. The Construction of Religious Boundaries: Culture, Identity, and Diversity in the Sikh Tradition. Chicago: University of Chicago Press, 1994.

Patton, Laurie L., ed. Authority, Anxiety, and Canon: Essays in Vedic Interpretation. SUNY series in Hindu studies. Albany: State University of New York Press, 1994.

Phojadāra, Ratana. Yogeśvara Guru Gañgeśvara Vol. I. Ahmedabad: Pārizād Prințerī, 1965.

Phojadāra, Ratana. Yogeśvara Guru Gañgeśvara Vol. II. Ahmedabad: Pārizād Prințerī, 1979.

Piano, Stefano. "A Proposito Delle Murti Dei Veda." In Bandhu: Scritti in Onore Di Carlo Della Casa; in Occasione Del Suo $70^{\circ}$ Compleanno. Edited by Renato Arena et al. Alessandria: Ed. dell'Orso, 1997.

Sandhu, Kiranjeet. "The Udāsīs in the Colonial Punjab 1849 AD-1947 AD." PhD Diss., Guru Nanak Dev University, 2011.

Sarasvati, Dayananda, and Chiranjiva Bharadwaja. Light of truht [i.e. truth]: Or, An English translation of the Satyarth prakash, the well-known work of Swami Dayananda Saraswati. New ed. New Delhi: Sarvadeshik Arya Pratinidhi Sabha, 1975.

Scharfe, Hartmut. Education in Ancient India. Handbook of oriental studies. Section two, India v. 16. Leiden, Boston: Brill, 2002.

Shulman, David D. “The Enemy Within: Idealism and Dissent in South Indian Hinduism.” In Orthodoxy, Heterodoxy, and Dissent in India. Edited by David D. Shulman, Reuven Kahane and Shmuel N. Eisenstadt, 11-55. Religion and society 23. Berlin, New York: Mouton, 1984.

Simini, Florinda de. Of Gods and Books: Ritual and Knowledge Transmission in the Manuscript Cultures of Premodern India. Studies in manuscript cultures Volume 8. Berlin, Boston: De Gruyter, 2016. doi:10.1515/9783110478815.

Singh, Pashaura. The Guru Granth Sahib: Canon, Meaning, and Authority. New Delhi, New York: Oxford University Press, 2000.

Srinivasan, Doris M. Many Heads, Arms and Eyes: Origin, Meaning and Form of Multiplicity in Indian Art. Studies in Asian art and archaeology 2o. Leiden: Brill, 1997. Staal, Frits. "The Meaninglessness of Ritual." Numen 26, no. 1 (1979): 2-22.

Staal, Frits. Discovering the Vedas: Origins, Mantras, Rituals, Insights. New Delhi: Penguin, 2008.

Watts, James W. How and Why Books Matter: Essays on the Social Function of Iconic Texts. Comparative Research on Iconic and Performative Texts. Sheffield: Equinox Publishing, 2019. 
Yelle, Robert A. Explaining Mantras: Ritual, Rhetoric, and the Dream of a Natural Language in Hindu Tantra. Religion in History, Society, and Culture 3. New York, London: Routledge, 2003.

Zavos, John. "Defending Hindu Tradition: Sanatana Dharma as a Symbol of Orthodoxy in Colonial India." Religion 31, no. 2 (2001): 109-23. doi:10.10o6/reli.2001.0322. 